\title{
Dinamika Komunikasi Antarbudaya Mahasiswa Suku Non Jawa di Universitas Muhammadiyah Magelang
}

\author{
Sihabuddin ${ }^{1}$ \\ sihabuddin@ummgl.ac.id
}

\begin{abstract}
Abstrak
Latar belakang penelitian ini untuk mengetahui bagaimana mahasiswa suku non Jawa di Universitas Muhammadiyah Magelang mengatasi kendala komunikasi antarbudaya yang pernah dialami selama masa kuliah. Adapun tujuan penilitian ini untuk menggambarkan dan menganalisis persepsi, proses adaptasi, dan cara membangun hubungan komunikasi antarbudaya mahasiswa suku non Jawa. Sedangkan metode penelitian menggunakan metode kualitatif dengan pendekatan studi kasus. Hasil penelitian menunjukan bahwasannya mahasiswa suku non Jawa pada awalnya menganggap bahasa Jawa bahasa yang rumit, asing, bahkan terasa menggelikan. Namun, lama kelamaan mahasiswa suku non Jawa menilai komunikasi orang Jawa keunikannya medok, sopan, halus dengan nada yang pelan dan lebih berhati-hati serta bertingkat. Proses adaptasi dimulai dari kesadaraan diri akan pentingnya beradaptasi, dilanjutkan dengan belajar, dan terakhir belajar dengan mempraktikkan. Dalam membangun hubungan komunikasi antarbudaya yang semakin erat ialah mendahulukan berpikir positif, mengamati bahasa dan sifat orang Jawa terlebih dahulu sehingga bisa menyesuaikan gaya komunikasi dengan orang Jawa tanpa meninggalkan identitas bahwasannya bukan orang Jawa serta meningkatkan intensitas komunikasi Antarbudaya.
\end{abstract}

Kata Kunci: Adaptasi, Komunikasi Antarbudaya, Mahasiswa, Persepsi

\begin{abstract}
The background of this research is to find out how non-Javanese students at the University of Muhammadiyah Magelang overcame the obstacles of intercultural communication that had been experienced during college. The purpose of this research is to describe and analyze perceptions, adaptation processes, and how to establish intercultural communication relationships non-Javanese students. While the research method uses qualitative methods with a case study approach. The results showed that the non-Javanese students at first considered the language of Javanese as a complicated, foreign language, even ridiculous. However, over time non-Javanese students assessed the Javanese communication as unique, polite, refined in a slow and more careful and multilevel tone. The process of adaptation starts from the awareness of the importance of adapting, followed by learning, and finally learning by practicing. In developing a thigh intercultural communication relations, it prioritizes positive thinking, observing the language and nature of Javanese people first so that they can adjust their style of communication with the Javanese without leaving the identity that they are not Javanese and increase the intensity of intercultural communication.

Keywords: Adaptation, Intercultural communication, Perceptions, Students
\end{abstract}

\section{Pendahuluan}

Universitas Muhammadiyah Magelang terletak di Provinsi Jawa Tengah yang penduduknya beretnis Jawa dengan kebudayaan dan bahasa yang khas. Kota

${ }^{1}$ Korespondensi: Sihabbudin, Program Studi Ilmu Komunikasi, Fakultas Psikologi dan Humaniora, Universitas Muhammadiyah Magelang, Jl. Tidar 21 Magelang 56126, Telp. (0293) 362082 
Magelang kota dimana Universitas Muhammadiyah Magelang berdiri dikenal sebagai kota dengan penduduk yang homogen yang tentunya mempengaruhi terhadap jenis suku yang menempuh pendidikan di Universitas Muhammadiyah Magelang sehingga sebagian besar mahasiswa Universitas Muhammadiyah Magelang beretnis Jawa. Namun, meski mayoritas besar bersuku Jawa mahasiswa di Universitas Muhammadiyah Magelang juga banyak yang dari suku lain yang berasal dari berbagai Provinsi di Indonesia.

Berdasarkan data dari sambutan dan laporan rektor UMMagelang Milad ke 54 tahun 2018 (2018), sebaran wilayah mahasiswa Universitas Muhammadiyah Magelang mencapai 27 provinsi dari 6 pulau (Jawa, Sumatera, Sulawesi, Kalimantan, Bali dan Nusa Tenggara, serta Papua) di Indonesia. Mayoritas mahasiswa Universitas Muhammadiyah Magelang berasal dari Jawa sejumlah 4.725 mahasiswa, Sumatera 38 mahasiswa, Sulawesi tiga mahasiswa, Bali dan Nusa Tenggara lima mahasiswa, dan Papua sejumlah dua mahasiswa.

Sebaran jumlah mahasiswa berdasarkan pulau bukan berarti mahasiswa tersebut dari suku tertentu, seperti mahasiswa yang berasal dari pulau Jawa belum tentu mahasiswa tersebut bersuku Jawa, bisa jadi suku Sunda, Banten atau Madura yang memiliki budaya dan bahasa yang berbeda dengan suku Jawa. Begitu pula dengan mahasiswa yang berasal dari pulau Sumatera, belum tentu mahasiswa tersebut suku Melayu atau suku-suku asli Sumatera, bisa jadi mahasiswa tersebut suku Jawa yang tinggal di pulau Sumatera. Pada penelitian ini fokus pada mahasiswa Universitas Muhammadiyah Magelang berdasarkan suku (non Jawa) bukan berdasarkan pulau meskipun suku tertentu identik dengan pulau atau wilayah tertentu. Seperti suku Bima dan Sumbawa dari Provinsi Nusa Tenggara Barat, suku Aceh dari Provinsi Nangroe Aceh Darussalam, suku Banten dari Provinsi Banten, Suku Sunda dari Provinsi Jawa Barat dan suku lainnya dari berbagai daerah di seluruh Indonesia.

Mahasiswa dari berbagai suku yang menempuh pendidikan di Universitas Muhammadiyah Magelang tersebut tentunya memiliki budaya yang berbeda dengan suku Jawa. Sehingga mahasiswa tersebut menemukan budaya baru yang harus diikuti atau menyesuaikan dengan budaya yang baru ditemuinya sebab mahasiswa tersebut merupakan pendatang yang minoritas. Menurut penulis, dalam konteks komunikasi sosial, mayoritas adalah pemenang dalam menentukan bagaimana budaya komunikasi 
dalam kegiatan sehari-hari, karena efektifitas komunikasi adalah kesepakatan bersama antara para anggota komunikasi yang akhirnya menjadi identitas suatu kelompok budaya. Misalnya dalam suku Jawa sebutan untuk rumah adalah "Omah" sebutan untuk anak laki-laki "lanang" dan berbagai contoh lainnya. Penyebutan terhadap sesuatu dalam bahasa Jawa yang dituturkan oleh suku Jawa karena kesepakatan orang Jawa, kalau orang Jawa tidak sepakat dengan penyebutan terhadap sesuatu maka kata tersebut tidak akan digunakan. Kesepakatan bersama inilah yang menjadi identitas suatu budaya. Jadi orang yang dari budaya lain jika ingin tinggal di tengah-tengah suku Jawa mau tidak mau harus menyesuaikan dengan budaya Jawa agar mudah dalam menjalin hubungan dalam kehidupan sehari-hari.

Meski harus menyesuaikan dengan budaya baru mahasiswa suku non Jawa tidak harus meninggalkan budaya lama yang telah menjadi identitas diri dan kelompoknya. Tapi mahasiswa tersebut harus tahu menempatkan atau menyesuaikan diri dengan budaya lingkungan sekitar terutama dalam hal komunikasi, sehingga terjadilah komunikasi antarbudaya antara mahasiswa suku non Jawa di Universitas Muhammadiyah Magelang dengan orang-orang di sekitarnya. Komunikasi antarbudaya sebenarnya sama dengan komunikasi antarpribadi, namun pada kajian komunikasi antarbudaya lebih menekankan perbedaan kebudayaan di antara para peserta komunikasi, baik komunikator maupun komunikan. Karena melihat dan menekankan perbedaan dalam segi kebudayaan, komunikasi antarbudaya lebih rumit dan lebih menarik untuk dikaji karena banyak kasus-kasus komunikasi yang terjadi dalam konteks komunikasi antarbudaya. Bahkan banyak dari kasus komunikasi antarbudaya berakibat fatal pada kedua belah pihak disebabkan banyak hal.

Seperti hasil penelitian yang dilakukan oleh Kholil, Mailin, \& Siregar (2017) bahwasannya komunikasi antarbudaya mahasiswa Malaysia dan Indonesia di Fakultas Dakwah dan Komunikasi Universitas Islam Negeri (UIN) ternyata tidak efektif. Hal ini karena interaksi komunikasi antarbudaya mahasiswa Malaysia dan Indonesia seperlunya saja, karena mahasiswa Malaysia sulit beradaptasi dan membiasakan diri dengan lingkungan baru yang dihadapi. Sehingga hubungan antarbudaya keduanya tidak harmonis. Dikarenakan persepsi masing-masing antara mahasiswa Malaysia dan Indonesia di FDK UIN SU saling bertolak belakang, diantaranya adalah menyangkut sikap yang ada dalam diri kedua budaya, serta 
menyimpulkan hal-hal yang menimbulkan prasangka antarkedua budaya tersebut. Menurut Shuter (2017) untuk mencapai dialog antarbudaya, komunikator harus memiliki hubungan yang terbuka, empatik, dan menerima karakteristik yang sulit dicapai dalam pertemuan tatap muka.

Begitu pula dengan kasus-kasus komunikasi antarbudaya yang terjadi di Universitas Muhammadiyah Magelang. Banyak kasus komunikasi antarbudaya terutama pada awal-awal masa perkuliahan. Kasus-kasus ini terjadi karena perbedaan atau kesalahan persepsi yang berawal dari ketidakpahaman mahasiswa non Jawa. Seperti yang peneliti temukan saat berbincang-bincang dengan mahasiswi asal Kuningan yang menuturkan.

"Ada beberapa perbedaan makna kata yang saya temukan waktu awal-awal di Magelang antara bahasa Sunda dengan babasa Jawa meski katanya sama. Seperti kata "Dabar", awalnya saya terkejut kata Dahar digunakan untuk berkomunikasi dengan orang yang lebih tua, karena di Kuningan kata "Dahar" sangat kasar tidak pantas untuk digunakan untuk yang lebih tua, termyata di Magelang kata "Dahar" itu bahasa yang halus," (Safitri, 2018)

Selain kasus karena kesalahan persepsi, masalah bahasa merupakan kendala terbesar dalam komunikasi antarbudaya yang dialami oleh mahasiswa suku non Jawa di Universitas Muhammadiyah Magelang. Hampir semua mahasiswa yang peneliti temui mengungkapkan hal yang sama terkait masalah bahasa. Seperti yang dituturkan oleh Jopri Hendriadi mahasiswa asal Sumbawa Nusa Tenggara Barat

"Awal-awal kuliah adalah masa-masa yang sulit bagi saya Pak, saya harus beradaptasi dengan lingkungan di sini. Terutama masalah bahasa, saat waktu istirahat banyak temanteman bercanda dengan bahasa Jawa mereka tertawa saya hanya diam bingung dengan yang mereka bicarakan" (Hendriadi, 2018)

Selain masalah bahasa, banyak kasus-kasus lain yang peneliti temukan terkait dengan komunikasi antarbudaya saat berbincang-bincang dengan mahasiswa suku non Jawa. Meskipun mengalami banyak kesulitan pada awal-awal kuliah, mahasiswa suku non Jawa mampu melewati kendala-kendala komunikasi antarbudaya tersebut dengan berbagai cara seperti dengan adaptasi dengan lingkungan baru dan membangun hubungan dengan mayoritas teman-temannya yang suku Jawa. Berdasarkan hasil penelitian yang dilakukan oleh Arianto (2015) bahwasannya untuk menuju persahabatan beda etnis mahasiswa FISIP Universitas Tadulako melalui 
tahap orientasi yang merupakan tahapan paling awal dari komunikasi antarpribadi yang terjadi pada tingkat pribadi masing-masing. Kemudian berlanjut pada tahap "tanpa beban dan santai" dimana komunikasi sering berjalan secara spontan dan membuat keputusan yang cepat dan tahap terakhir komunikasi terjadi dengan saling kritik karena penggunaan bahasa daerah masing-masing atau kesalahan interpretasi komunikasi diantara pihak namun belum mampu mengancam persahabatan yang telah terbina.

Penelitian ini berbeda dengan penelitian yang dilakukan oleh Arianto yang lebih menekankan pada komunikasi antarpribadi dalam konteks mahasiswa beda etnies. Penelitian ini lebih menekankan pada komunikasi antarbudaya di antara pribadi mahasiswa yang berbeda kebudayaan dengan tujuan lebih spesifik untuk mengetahui persepsi, proses adaptasi, dan cara membangun hubungan komunikasi antarbudaya mahasiswa suku non Jawa di Universitas Muhammadiyah Magelang.

\section{Tinjauan Pustaka}

\section{Komunikasi Antarbudaya}

Komunikasi antarbudaya memiliki banyak definisi menurut Porter dan Samovar komunikasi antarbudaya terjadi bila produsen pesan adalah anggota suatu budaya dan penerima pesannya adalah anggota suatu budaya lainnya. Sedangkan Tubbs dan Moss mendefinisikan komunikasi antarabudaya adalah komunikasi antara orang-orang yang berbeda budaya (baik dalam arti ras, etnik, atau perbedaanperbedaan sosioekonomi). Berbeda dengan Carley H. Dood yang mendefinisikan komunikasi antarbudaya sebagai pengiriman dan penerimaan pesan-pesan dalam konteks perbedaan kebudayaan yang menghasilkan efek-efek yang berbeda. Berbeda pula dengan Young Yun Kim yang mendefinisikan komunikasi antarbudaya sebagai suatu peristiwa yang merujuk di mana orang - orang yang terlibat di dalamnya baik secara langsung maupun tidak langsung memiliki latar belakang budaya yang berbeda (Halik, 2015).

Mulyana dan Rakhmat (2010) menjelaskan komunikasi antarbudaya terjadi bila produsen pesan adalah suatu anggota budaya dan penerima pesannya adalah anggota suatu budaya lainnya. Dengan demikian, akan segera dihadapkan pada masalah-masalah yang ada dalam suatu situasi yang dimana suatu pesan disandi dalam 
suatu budaya dan harus disandi dalam budaya yang lain. Seperti yang telah diketahui budaya mempengaruhi orang yang berkomunikasi. Budaya bertanggung jawab atas seluruh perbendaharaan perilaku komunikatif dan makna yang dimiliki setiap orang. Konsekuensinya, perbendaharaan-perbendaharaan yang dimiliki dua orang yang berbeda budaya akan berbeda pula yang dapat menimbulkan segala macam kesulitan.

\section{Persepsi, Adaptasi, dan Hubungan Komunikasi Antarbudaya}

Persepsi dalam Dayakisni dan Yuniardi disebut sebagai inti dari komunikasi, karena jika persepsi seseorang tidak akurat, tidak mungkin akan mampu berkomunikasi dengan efektif. Persepsilah yang nantinya akan menentukan seseorang memilih suatu pesan dan mengabaikan pesan lainnya. Hal ini memberikan pemahaman, bahwa semakin tinggi derajat kesamaan persepsi individu satu dengan individu lain, maka akan semakin mudah dan semakin sering mereka melakukan komunikasi, dan konsekuensinya semakin cenderung membentuk kelompok budaya atau kelompok identitas (Kholil, Mailin, \& Siregar, 2017). Latar belakang budaya seseorang akan memberikan pengaruh pada persepsinya. Latar belakang tersebut meliputi kepercayaan, norma dan nilai yang akan menjadi sebuah makna yang dipahami untuk membentuk suatu penilaian terhadap orang lain (Hadawiyah, 2016).

Adapun adaptasi komunikasi antarbudaya merupakan suatu problema yang perlu dipecahkan ketika seseorang ataupun sekelompok orang berkomunikasi dengan pihak lain yang berbeda budaya. Adaptasi dalam kajian komunikasi antarbudaya ini pada umumnya dihubungkan dengan perubahan dari masyarakat atau bagian dari masyarakat. Seseorang yang memilih strategi adaptif cenderung memiliki kesadaran yang tinggi terhadap harapan dan tuntutan dari lingkungannya, sehingga siap untuk mengubah perilaku (Utami, 2015). Menurut Kim, proses adaptasi antarbudaya merupakan proses interaktif yang berkembang melalui kegiatan komunikasi individu pendatang dengan lingkungan sosial budayanya yang baru. Adaptasi antarbudaya tercermin pada adanya kesesuaian antara pola komunikasi pendatang dengan pola komunikasi yang diharapkan atau disepakati oleh masyarakat dan budaya lokal/setempat. Begitupun sebaliknya, kesesuaian pola komunikasi inipun menunjang terjadinya adaptasi antarbudaya (Utami, 2015). 
Dalam komunikasi antarbudaya pasti terjadi hubungan antarpribadi, maka dari itu Komunikasi antarbudaya diartikan sebagai komunikasi antarpribadi yang dilakukan oleh mereka yang berbeda latar belakang kebudayaan (Karim, 2015). Komunikasi antarpribadi menurut Devito berupaya mengembangkan hubungan antar sesama manusia, tujuannya mengurangi kesepian, mendapatkan pengetahuan atau informasi, sampai menjalin suatu hubungan persahabatan yang akrab (Arianto, 2015).

\section{Teori Akomodasi Komunikasi}

Teori akomodasi komunikasi merupakan teori dari Howard Giles. Akomodasi dapat didefinisikan sebagai kemampuan menyesuaikan, memodifikasi atau mengatur perilaku seseorang dalam responnya terhadap orang lain. Jadi teori akomodasi komunikasi adalah teori yang berfokus pada perilaku seseorang dalam memilih untuk mengatur atau memodifikasi cara berkomunikasinya terhadap respons yang didapat pada saat berkomunikasi. Ada beberapa cara untuk beradaptasi dalam teori akomodasi, salah satu poin penting dalam teori akomodasi komunikasi bahwa dalam berkomunikasi setiap orang punya pilihan dalam menentukan sikap komunikasinya yaitu dengan cara konvergensi, divergensi, dan akomodasi berlebihan (Riandy F, 2016).

Adapun penjelasan konvergensi, divergensi, dan akomodasi berlebihan dalam Yasir (Riandy F, 2016) sebagai berikut:

1) Konvegensi adalah strategi dimana individu beradaptasi terhadap perilaku komunikatif satu sama lain. Orang akan beradaptasi terhadap kecepatan bicara, jeda, senyuman, tatapan mata, dan perilaku verbal dan nonverbal lainnya. Ketika orang melakukan konvergensi, tergantung pada persepsi orang tersebut mengenai tuturan atau perilaku orang lainnya. Selain itu, konvergensi juga didasarkan pada ketertarikan. Biasanya para komunikator saling tertarik dan akan melakukan konvergensi dalam percakapan.

2) Divergensi adalah cara dan strategi ini merupakan salah satu bentuk tindakan untuk mempertahankan perbedaan diantara para komunikator, dalam hal ini divergensi adalah strategi yang digunakan untuk menonjolkan perbedaan verbal dan nonverbal di antara para komunikator, atau bisa dibilang divergensi ini bertolak belakang dengan konvergensi. Namun perlu 
ditegaskan bahwa divergensi bukanlah cara untuk menunjukkan ketidaksepakatan. Divergensi tidak sama dengan ketidakpedulian. Seseorang melakukan divergensi untuk mempertahankan warisan budayanya.

3) Akomodasi berlebihan, dalam hal ini komunikator mencoba untuk melakukan akomodasi secara berlebihan dalam mengatur, memodifikasi, dan merespons orang lain. Walaupun komunikator berniat baik tetapi sering disalahartikan dengan niat yang buruk, terlebih melecehkan.

Teori akomodasi komunikasi memiliki empat asumsi dasar, dalam West dan Turner (2008) disebutkan bahwa akomodasi dipengaruhi oleh beberapa keadaan personal, situasional dan budaya, akhirnya diidentifikasi dengan beberapa asumsi antara lain: 1) Persamaan dan perbedaan berbicara dan perilaku terdapat di dalam semua percakapan; 2) Cara dimana mempersepsikan tuturan dan perilaku orang lain akan menentukan bagaimana mengevaluasi sebuah percakapan; 3) Bahasa dan perilaku memberikan informasi mengenai status sosial dan keanggotaan kelompok; 4) Akomodasi bervariasi dalam hal tingkat kesesuain, dan norma mengarahkan proses akomodasi.

\section{Metode Penelitian}

Metode penelitian ini menggunakan metode deskriptif kualitatif dengan pendekatan studi kasus. Penelitian dilakukan di Universitas Muhammadiyah Magelang pada bulan Januari sampai Februari tahun 2019. Sedangkan subjek penelitiannya ialah mahasiswa suku non Jawa di Universitas Muhammadiyah Magelang yang terdiri dari Suku Sunda, Bima, Sumbawa, Banten, Dobo (Kep Aru Maluku), dan Pakpak Boang (Aceh) dengan jumlah 8 (delapan) narasumber yang dinilai mewakili mahasiswa suku non-Jawa lainnya dan minimal lebih dari enam bulan tinggal di Magelang. Pengumpulan data dilakukan dengan wawancara mendalam dan metode dokumenter dengan menggunakan teknik snowball sampling. Analisis data peneliti melakukannya bersamaan dengan proses pengumpulan data. Setelah mereduksi data ketika data-data terkumpul, peneliti memilih hal-hal pokok yang sesuai dengan fokus penelitian. Selanjutnya menarik kesimpulan dengan menarik keterkaitan antara data yang sudah direduksi oleh peneliti dan teori yang digunakan. 


\section{Hasil dan Pembahasan}

\section{Persepsi Mahasiswa Suku Non Jawa Terhadap Komunikasi Suku Jawa}

Mahasiswa suku non Jawa pada awalnya rata-rata menganggap bahasa Jawa adalah bahasa yang rumit, asing di telinga bahkan terasa menggelikan karena memiliki banyak perbedaan dengan bahasa daerah asal. Namun, lama kelamaan penilaianpun berbeda. Mahasiswa suku non Jawa menilai komunikasi orang Jawa keunikannya medok, sopan, halus dengan nada yang pelan dan lebih berhati-hati serta bertingkat. Tingkatan bahasa Jawa dinilai sama dengan bahasa daerah lain di Indonesia yang memiliki tingkatan, sehingga menyebabkan mahasiswa suku non Jawa semakin menyukai bahasa Jawa dan juga atas kesadaran sendiri berkaitan dengan kebutuhan berkomunikasi di tengah-tengah orang Jawa.

Kesalahan persepsi tersebut dikarenakan perbedaan latar belakang budaya dan minimnya pengetahuan tentang bahasa dan budaya Jawa, seperti yang dituturkan mahasiwa asal Maluku yang menganggap bahasa Jawa seperti tidak ada titik dan komanya meskipun bernada pelan. Setelah pengetahuan tentang bahasa dan budaya Jawa bertambah, maka persepsinya ikut berubah, bahkan menjadi suka bahasa Jawa. Pengetahuan sangat berpengaruh terhadap persepsi suatu budaya, termasuk dalam komunikasi. Hal ini sesuai dengan yang dijelaskan Hadawiyah (2016) latar belakang budaya seseorang akan memberikan pengaruh pada persepsinya. Latar belakang tersebut meliputi kepercayaan, norma dan nilai yang akan menjadi sebuah makna yang dipahami untuk membentuk suatu penilaian terhadap orang lain.

Perubahan persepsi yang positif terhadap bahasa dan budaya Jawa menjadi gerbang efektifitas komunikasi antarbudaya mahasiswa suku non Jawa. Persepsi positif ini membawa kesamaan persepsi terhadap lawan bicara yang berbeda latar belakang budaya, karena setiap pemilik budaya tentunya akan menilai positif terhadap budaya yang dianut, termasuk mahasiswa suku Jawa di Magelang. Dari kesamaan persepsi inilah komunikasi menjadi efektif karena persepsi adalah inti dari komunikasi. Seperti yang dijelaskan Dayakisni dan Yuniardi dalam Kholil, Mailin, \& Siregar (2017) yang mengatakan persepsi disebut sebagai inti dari komunikasi, karena jika persepsi seseorang tidak akurat, tidak mungkin akan mampu berkomunikasi dengan efektif. Persepsilah yang nantinya akan menentukan seseorang memilih suatu pesan dan mengabaikan pesan lainnya. Hal ini memberikan pemahaman, bahwa 
semakin tinggi derajat kesamaan persepsi individu satu dengan individu lain, maka akan semakin mudah dan semakin sering mereka melakukan komunikasi, dan konsekuensinya semakin cenderung membentuk kelompok budaya atau kelompok identitas.

Persepsi positif ini menjadi titik awal mahasiswa suku non Jawa adaptasi dengan budaya sekitar dan membangun hubungan dengan orang-orang di sekitarnya. Persepsi positif ini menjadikan intensitas komunikasi semakin tinggi dan semakin paham untuk memilih suatu pesan untuk digunakan dan mengabaikan pesan yang lain, seperti yang dilakukan oleh beberapa mahasiswa untuk memasukkan beberapa kosa kata bahasa Jawa di dalam bahasa Indonesia yang digunakan sehari-hari seperti pada kalimat "Enggih, akan saya nggarap tugasnya Pak" jika diperintah oleh Dosen. Selain itu, dengan semakin mengetahui gaya berbicara orang Jawa yang pelan dan sopan menjadikan mahasiswa suku non Jawa yang terbiasa berkomunikasi dengan nada yang tinggi mencoba untuk memelankan pembicaraannya agar dipandang sopan oleh orang-orang di sekitarnya. Seperti pada pengucapakan kata "Enggih......" dengan menarik akhir kata dalam pengucapan seperti halnya orang Jawa pada umumnya. Tidak hanya itu, pemilihan pesan waktu memperkenalkan diri bukan orang Jawa merupakan bentuk dari persepsi yang menyadari latar belakang budaya yang dianut sebelumnya berbeda dengan orang Jawa.

Teori akomodasi komunikasi dari Howard Giles salah satu asumsinya ialah cara dimana mempersepsikan tuturan dan perilaku orang lain akan menentukan bagaimana mengevaluasi sebuah percakapan (West dan Turner, 2008). Dalam teori ini persepsi memiliki perananan sangat penting seperti yang dijelaskan dalam salah satu asumsinya, persepsi sangat menentukan dalam mengevaluasi sebuah percakapan. Teori ini fokus pada perilaku seseorang dalam memilih dan mengatur cara berkomunikasi terhadap respon yang didapat saat berkomunikasi. Melihat dari hasil penelitian ini bahwasannya persepsi yang menentukan cara-cara perilaku komunikasi mahasiswa suku non Jawa dalam berkomunikasi antarbudaya seperti memasukan beberapa kosa kata bahasa Jawa dalam menggunakan bahasa Indonesia, berusaha memelankan pembicaraan, dan memperkenalkan diri bahwasannya bukan orang Jawa merupakan bukti kesesuaian dan kebenaran teori ini dengan temuan penelitian terkait dengan persepsi. Selain itu, seperti yang telah dijelaskan pada paragraf sebelumnya, 
persepsi positif merupakan awal mahasiswa suku non Jawa dalam melakukan adaptasi dengan lingkungan budaya sekitar dan membangun hubungan dengan orang-orang yang berbeda latar belakang budaya baik itu dengan konvergensi, divergensi, atau akomodasi berlebihan.

\section{Proses Adaptasi Komunikasi Antarbudaya Mahasiswa Suku Non Jawa}

Proses adaptasi komunikasi antabudaya mahasiswa suku non Jawa diawali dengan kesadaran diri akan pentingnya menyesuaikan diri dengan lingkungan baru. Dari kesadaran diri tersebut muncul keinginan untuk belajar yaitu proses kedua dengan cara membaur dengan orang-orang sekitar yang diawali dengan mengamati budaya termasuk bahasa yang digunakan sehari-hari. Selain mengamati juga bertanya arti dari sebuah kata atau kalimat bahkan meminta untuk mengulanginya. Setelah itu, masuk pada proses terakhir yaitu belajar sambil mempraktikan apa yang telah diketahui dengan mengucapkan sedikit-sedikit kata atau kalimat berbahasa Jawa dalam bahasa Indonesia. Meskipun sampai saat ini masih banyak yang hanya memahami tapi belum bisa mempraktikan secara penuh. Di samping itu, mahasiswa suku non Jawa juga meminta teman-temannya untuk memahami bahwasannya dirinya bukan orang Jawa dan memaklumi jika gaya komunikasinya berbeda dengan orang-orang Jawa.

Proses adaptasi komunikasi antarbudaya mahasiswa suku non Jawa sesuai dengan pernyataan Utami dalam jurnalnya yang berjudul Teori-Teori Adaptasi Antarbudaya (2015) yang menyatakan adaptasi komunikasi antarbudaya merupakan suatu problema yang perlu dipecahkan ketika seseorang ataupun sekelompok orang berkomunikasi dengan pihak lain yang berbeda budaya. Adaptasi dalam kajian komunikasi antarbudaya ini pada umumnya dihubungkan dengan perubahan dari masyarakat atau bagian dari masyarakat. Seseorang yang memilih strategi adaptif cenderung memiliki kesadaran yang tinggi terhadap harapan dan tuntutan dari lingkungannya, sehingga siap untuk mengubah perilaku.

Mahasiswa suku non Jawa yang merupakan bagian dari masyarakat awalnya mengalami problem secara komunikasi maupun budaya. Atas kesadaran diri problem ini perlu dipecahkan untuk keberlangsung kegiatan perkuliahan di Universitas Muhammadiyah Magelang. Problem atau kendala tersebut selain bahasa, 
juga budaya, dan makanan. Kendala bahasa terletak pada ketidakpahaman terhadap bahasa Jawa. Sedangkan kendala budaya terletak pada cara berbicara orang jawa yang bernada pelan, halus, sopan dan sedikit tidak berterus terang karena mengutamakan rasa tidak enak untuk menolak. Seperti yang diungkapkan mahasiswa asal Bima "Teman-teman di sini kalau berbicara dengan orang lain cenderung tidak berterus terang, hanya senyum-senyum seperti mengiyakan padahal kenyatannya tidak demikian, berbeda dengan di rumab saya yang langsung berani menolak" (Ningrum, 2019). Tentunya hal ini berbeda dengan budaya asal mereka yang budaya berbicaranya bernada tinggi dan sedikit blakblakan. Adapun kendala makanan, masakan Jawa dinilai terlalu manis sehingga tidak cocok dengan lidah mereka. Seperti yang diungkapkan oleh mahasiswa asal Kuningan "Kalau kendala masakan, menurut saya di sini masakannya terlalu manis pak,", (Safitri, 2019). Dari kendala-kendala tersebut para mahasiswa suku non Jawa belajar untuk berubah sesuai dengan budaya yang baru. Proses berubah untuk menyesuaikan diri seperti yang telah disebutkan di atas meliputi tiga proses yaitu kesadaran diri, belajar, dan belajar sambil mempraktikkan.

Menurut Kim dalam Utami (2015) proses adaptasi antarbudaya merupakan proses interaktif yang berkembang melalui kegiatan komunikasi individu pendatang dengan lingkungan sosial budayanya yang baru. Adaptasi antarbudaya tercermin pada adanya kesesuaian antara pola komunikasi pendatang dengan pola komunikasi yang diharapkan atau disepakati oleh masyarakat dan budaya lokal/setempat. Begitupun sebaliknya, kesesuaian pola komunikasi inipun menunjang terjadinya adaptasi antarbudaya (Utami, 2015). Mahasiswa suku non Jawa dalam proses kedua yaitu belajar tidak hanya mengamati saja tapi juga belajar dengan bertanya apa arti sebuah kata atau kalimat bahkan meminta untuk mengulanginya. Seperti yang dijelakan oleh mahasiswa asal Bima "Saya sering meminta teman-teman untuk mengulangi kata yang disampaikan, dan mereka senang hati memberi tabu" (Tildjuir, 2019). Dalam proses belajar tersebut tentunya ada proses interaksi melalui kegiatan komunikasi mahasiswa suku non Jawa sebagai pendatang dengan lingkungan sosial budayanya yang baru. Pada proses ketiga yaitu belajar sambil mempraktikkan dengan sedikit-sedikit kata atau kalimat dalam bahasa Jawa dalam berkomunikasi dengan orang lain dan meminta orang-orang di sekitarnya untuk memaklumi bahwasannya bukan orang Jawa. Dalam melakukan praktik bahasa Jawa tersebut tentunya harus 
menyesuaikan pola komunikasi di antara kedua orang yang berbeda latar belakang budaya tersebut dengan pola komunikasi yang disepakati masyarakat setempat. Misalnya dalam mengucapkan kata "Iyo atau enggih," dengan nada yang disesuaikan dengan nada bicara yang biasanya diucapkan orang Jawa.

Dalam teori akmodasi komunikasi dijelaskan bahwa dalam berkomunikasi setiap orang punya pilihan dalam menentukan sikap komunikasinya yaitu dengan cara konvergensi, divergensi, dan akomodasi berlebihan (Riandy F, 2016). Dalam proses adaptasi ini mahasiswa suku non Jawa di Universitas Muhammadiyah Magelang dengan menentukan sikap komunikasinya dengan cara konvergensi. Konvergensi dalam Riandy F (2016) adalah strategi dimana individu beradaptasi terhadap perilaku komunikasi satu sama lain. Orang akan beradaptasi terhadap kecepatan bicara, jeda, senyuman, tatapan mata, dan perilaku verbal dan nonverbal lainnya. Ketika orang melakukan konvergensi, tergantung pada persepsi orang tersebut mengenai tuturan atau perilaku orang lainnya. Selain itu, konvergensi juga didasarkan pada ketertarikan. Biasanya para komunikator saling tertarik dan akan melakukan konvergensi dalam percakapan.

Konvergensi yang dilakukan dalam proses adaptasi mahasiswa suku non Jawa selain terkadang menggunakan bahasa Jawa sedikit-sedikit dengan gaya medok menurut persepsinya yang diselang-seling dengan bahasa Indonesia juga memelankan pembicaraan, sering tersenyum, dan bernada sopan seperti orang Jawa pada umumnya. Semua ini dilakukan selain karena kesadaran diri akan pentingnya kebutuhan dasar untuk membangun hubungan komunikasi yang lebih efektif, juga karena ketertarikan mempelajari bahasa Jawa yang dianggap unik. Selain itu, dalam melakukan cara konvergensi para mahasiswa suku non Jawa tersebut mengikuti berbagai kegiatan di kampus yang terbukti menunjang proses adaptasi. Sebenarnya tiga proses adaptasi mahasiswa suku non Jawa yang telah dijabarkan di atas merupakan cara konvergensi karena hal-hal tersebut merupakan bentuk ketertarikan dan strategi dalam melakukan konvergensi dan pastinya ada unsur komunikasi nonvebal. 


\section{Membangun Hubungan Komunikasi Antarbudaya Mahasiswa Suku Non} Jawa

Dalam membangun hubungan komunikasi antarbudaya mahasiswa suku non Jawa mendahulukan berpikir positif dan mengamati bahasa dan sifat orang Jawa yang akan diajak berkomunikasi terlebih dahulu, sehingga bisa menyesuaikan komunikasi dengan orang tersebut tanpa meninggalkan identitasnya sebagai bukan orang Jawa serta meningkatkan intensitas komunikasi. Seperti yang disampaikan mahasiswa asal Aceh "Kalau saya melibat dulu sifat orang yang akan saya ajak berbicara dan mengamati cara berbicaranya apakah menghargai saya sebagai pendatang atau tidak, kalau orangnya enak saya sering bergaul dengan dia," (Rabudi, 2019). Menurut Devito upaya mengembangkan hubungan antar sesama manusia, tujuannya mengurangi kesepian, mendapatkan pengetahuan atau informasi, sampai menjalin suatu hubungan persahabatan yang akrab (Arianto, 2015). Menjalin hubungan yang akrab memang sangat dibutuhkan oleh setiap orang yang hidup di lingkungan budaya yang baru termasuk mahasiswa suku non Jawa.

Beberapa cara atau strategi yang dilakukan oleh mahasiswa suku non Jawa dalam menentukan sikap untuk membangun hubungan komunikasi antarbudaya dikaitkan dan dibahas sesuai dengan teori akomodasi komunikasi dari Howard Giles maka akan terbagi dengan tiga pembahasan sesuai dengan cara strategi dalam pembahasan teori tersebut yaitu konvergensi, divergensi, dan akomodasi berlebihan.

Konvergensi sendiri merupakan strategi individu beradaptasi terhadap perilaku komunikatif satu sama lain (Riandy F, 2016). Adapun strategi konvergensi yang dilakukan oleh Mahasiswa suku non Jawa untuk membangun hubungan lebih erat dengan orang-orang di sekitarnya selain berpikir positif dan menyapa terlebih dahulu tentunya meningkatkan intensitas komunikasi dengan banyak bertanya tentang bahasa dan budaya Jawa disertai dengan menjaga sikap dan kesopanan seperti halnya kebanyakan orang Jawa. Seperti yang dijelaskan mahasiswa asal Sumbawa "Sampai sekarang saya masih bertanya banyak, hal tentang bahasa dan budaya Jawa dan selalu menjaga sikap sepertinya halmya orang Jawa" (Ningrum, 2019). Tidak hanya sekedar itu membangun suasana kekeluargaan seperti di kampung dengan tolong menolong bisa membuat hubungan komunikasi antarbudaya semakin erat. Seperti yang dijelaskan oleh mahasiswa asal Kuningan "Saya selalu berusaha membangun kekeluargaan yang erat 
dengan teman-teman di sini dengan saling tolong menolong seperti di kampung” (Safitri, 2019). Berpikir positif sangat membantu untuk menghilangkan keragu-raguan dalam menyapa terlebih dahulu pada orang yang baru dikenal dan sangat membantu membuat hubungan lebih akrab setelah lebih lama saling kenal. Begitu pula dengan mengamati bahasa serta sifat orang Jawa hubungan komunikasi semakin erat karena memiliki pengetahuan sedikit banyak bagaimana cara berkomunikasi antarbudaya dengan orang Jawa. Seperti yang dijelaskan oleh mahasiswa asal Banten "Sebenarnya saya orangnya pendiam tapi kalau saya berpikir positif saja dan menyapa terlebih dahulu teman yang baru dikenal dan itu sangat membantu saya dalam proses adaptasi," (Afifah, 2019).

Sedangkan divergensi yang dilakukan oleh mahasiswa suku non Jawa dengan cara menunjukan bahwasannya bukan suku Jawa. Selain memperkenalkan diri juga meminta lawan bicara untuk menggunakan bahasa Indonesia jika berkomunikasi dengannya. Jika mau menggunakan bahasa Jawa yang dasar-dasar saja dan akan dijawab dengan bahasa Indonesia karena sadar baru bisa memahami belum bisa mengucapkan. Seperti yang diungkapkan oleh mahasiswa asal Kalimantan Timur bersuku Sunda "Saya sering meminta teman-teman untuk menjawab pertanyaan saya dengan bahasa Indonesia saja, atau menggunakan bahasa Jawa yang dasar karena saya belum fasih bahasa Jawa” (Ariyati, 2019). Selain itu, berbicara dengan bahasa asal masing-masing jika berkumpul dengan mahasiswa yang berasal dari daerah yang sama merupakan salah satu cara bahwasannya berasal dari budaya yang berbeda. Logat bicara pun juga menunjukan bahwasannya bukan orang Jawa. Seperti yang diungkapkan mahasiswa asal Bima "Kalau berkumpul dengan teman-teman asal, saya berbicara menggunakan bahasa daerah saya untuk. menunjukan kalau kami bukan orang Jawa” (Kaltsum, 2019). Tidak hanya itu, jika pulang kampung sering membawa oleh-oleh khas daerahnya masingmasing.

Adapun divergensi sendiri dalam teori akomodasi komunikasi Howard Giles dalam Riandy F (2016) merupakan salah satu bentuk tindakan untuk mempertahankan perbedaan diantara para komunikator, dalam hal ini divergensi adalah strategi yang digunakan untuk menonjolkan perbedaan verbal dan nonverbal di antara para komunikator. Namun perlu ditegaskan bahwa divergensi bukanlah cara untuk menunjukkan ketidaksepakatan, divergensi tidak sama dengan ketidakpedulian. Seseorang melakukan divergensi untuk mempertahankan warisan budayanya. 
Akomodasi berlebihan yang dilakukan mahasiswa suku non Jawa ialah menyisipkan bahasa Jawa sebisanya dalam percakapan dalam bahasa Indonesia, meskipun sering menjadi bahan tertawaan karena aksen dan logatnya tidak sesuai dengan aksen dan logat orang Jawa. Seperti yang diungkapkan oleh mahasiswa asal Sumbawa "Kalau saya yang penting bicara bahasa Jawa sama teman-teman tidak begitu peduli benar atau salah dulu, meskipun sering ditertawan teman-teman, karena katanya bahasa saya aneh,” (Ningrum, 2019). Namun, akomodasi berlebihan juga dilakukan oleh segelintir mahasiswa suku Jawa dengan meniru logat komunikasi suku non Jawa membuat mahasiswa suku non Jawa tersebut merasa diejek. Meskipun mahasiswa suku Jawa tidak ada niatan untuk mengejek. Seperti yang diungkapkan oleh mahasiswa asal Kuningan "Terkadang, setelah mereka tahu kalau saya bukan orang Jawa mereka berbicara bahasa Indonesia dengan logat bahasa daerah saya Pak, jujur terkadang saya merasa diejek tapi positif thinking saja" (Safitri, 2019). Adapun akomodasi berlebihan dalam Riandy F (2016) komunikator mencoba untuk melakukan akomodasi secara berlebihan dalam mengatur, memodifikasi, dan merespons orang lain. Walaupun komunikator berniat baik tetapi sering disalahartikan dengan niat yang buruk terlebih melecehkan.

\section{Kesimpulan}

Berdasarkan hasil deskripsi dan analisis sesuai dengan tujuan penelitian. Maka peneliti membuat kesimpulan bahwasannya persepsi mahasiswa suku non Jawa terhadap bahasa dan budaya Jawa pada awalnya menganggap bahasa Jawa, rumit, asing di telinga bahkan terasa menggelikan karena memiliki banyak perbedaan dengan bahasa daerah asal. Namun, lama kelamaan penilaianpun berbeda mahasiswa suku non Jawa tersebut menilai komunikasi orang Jawa keunikannya medok, sopan, halus dengan nada yang pelan dan lebih berhati-hati serta bertingkat. Hal ini menyebabkan mahasiswa suku non Jawa semakin menyukai bahasa Jawa dan juga atas kesadaran sendiri akan kebutuhan berkomunikasi ditengah-tengah orang Jawa.

Adapun proses adaptasi komunikasi antabudaya mahasiswa suku non Jawa diawali dengan kesadaran diri akan pentingnya menyesuaikan diri dengan lingkungan baru. Sehingga muncul keinginan untuk belajar yaitu proses kedua dengan cara membaur dengan orang-orang sekitar yang diawali dengan mengamati budaya termasuk bahasa yang digunakan sehari-hari. Selain mengamati juga bertanya arti dari 
sebuah kata atau kalimat bahkan meminta untuk mengulanginya. Setelah itu, masuk pada proses terakhir yaitu belajar sambil mempraktikan apa yang telah diketahui dengan mengucapkan sedikit-sedikit kata atau kalimat berbahasa Jawa dalam bahasa Indonesia. Meskipun sampai saat ini masih banyak yang hanya memahami tapi belum bisa mempraktikan secara penuh.

Sedangkan dalam membangun hubungan komunikasi antarbudaya mahasiswa suku non Jawa tersebut mendahulukan berpikir positif dan mengamati bahasa dan sifat orang Jawa yang akan diajak berkomunikasi terlebih dahulu sehingga bisa menyesuaikan komunikasi dengan orang tersebut tanpa meninggalkan identitasnya bahwasannya bukan orang Jawa serta meningkatkan intensitas komunikasi.

\section{Daftar Rujukan}

\section{Buku}

Sambutan dan Laporan Rektor UMMagelang Milad ke-54 tahun 2018 (2018) Laporan Tabunan Rektor Tabun Akademik 2017/2018. Universitas Muhammadiyah Magelang

Miles, M. B. (1992). Qualitative Data Analysis. Jakarta: UI Press.

Mulyana, D. (2013). Metode Penelitian Kualitatif. Bandung: Rosdakarya.

Mulyana, D. \& Rakhmat, J. (2010). Komunikasi Antarbudaya Panduan Berkomunikasi Dengan Orang-Orang Berbeda Budaya. Bandung: Rosdakarya

West, R. \& Turner, L. H. (2008) Pengantar Teori Komunikasi, edisi 3 analisis dan aplikasi, Jakarta: Salemba Humanika.

\section{Jurnal}

Ammaria, H. (2017). Komunikasi dan Budaya. Jurnal Peurawi Media Kajian Komunikasi Islam, Vol $\quad 1 \quad$ No $1 . \quad$ http://jurnal.arraniry.ac.id/index.php/peurawi/article/view/1992/0, diakses 28 November 2018 pukul 17:26 WIB.

Arianto. (2015). Menuju Persahabatan Melalui Komunikasi Antarpribadi Mahasiswa Beda Etnis . Kritis Jurnal Sosial Ilmu Politik Universitas Hasanudin, Vol 1 No 2. http://journal.unhas.ac.id/index.php/kritis/article/view/16, diakses 28 November 2018 pukul 20:23 WIB. 
Hadawiyah. (2016). Komunikasi Antarbudaya Pasangan Beda Etnis (Studi Fenomenologi Pasangan Beda Etnis Suku Sulawesi - Jawa di Makasar). Jurnal Lentera Komunikasi , Vol 2 No 1. https://plj.ac.id/ojs/index.php/jrksi/article/download/47/36, diakses 28 November 2018 pukul 16:59 WIB.

Halik, A. (2015). Peran Media Massa Dalam Komunikasi Antarbudaya. Jurnal AlKhitabah, Vol II, No 1, 83-92. http://journal.uinalauddin.ac.id/index.php/Al-Khitabah/article/ view/2621/2470, diakses 28 November 2018 pukul 17:23 WIB.

Karim, A. (2015). Komunikasi Antarbudaya Di Era Modern . At-Tabsyir Jurnal Komunikasi Penyiaran Islam , Vol 3, No 2. http://journal.stainkudus.ac.id/index.php/komunikasi/ article/ view/1650/1486, 28 November 2018 pukul 17:42 WIB.

Kholil, S. Mailin \& Siregar, I. L. (2017). Komunikasi Antarbudaya Mahasiswa Malaysia Dan Indonesia Fakultas Dakwah Dan Komunikasi Universitas Islam Negeri (UIN) Sumatera Utara. Al-Balagh, Vol 1 No 2. http://jurnal.uinsu.ac.id/index.php/balagh/article/view/1234/989, diakses 28 November 2018 pukul 17:30 WIB.

Riandy F, A. (2016). Akomodasi Komunikasi Dalam Interaksi Antarbudaya Pedagang Etnis Bugis Dan Minangkabau Di Pasar Induk Talang Banjar Jambi . $\begin{array}{llllll}\text { JOM FISIP } & \text { NOL } & \text { Vol } & 3 & \text { No }\end{array}$ https://jom.unri.ac.id/index.php/JOMFSIP/article/view/8681/8349, diakses 28 November 2018 pukul 20:32 WIB.

Shuter, R. (2017). New Media And Intercultural Communication. The International Encylopedia Of Intercultural Communication. https://onlinelibrary.wiley.com/doi/abs/10.1002/9781118783665.ieicc0 005, diakses 22 Desember 2018 pukul 14:04 WIB.

Sumantri, F. A. (2017). Hambatan Komunikasi Antarbudaya Mahasiswa Vietnam Di Universitas Tadulako. Jurnal Online Kinesike, Vol 4 No 2. http://jurnal.untad.ac.id/jurnal/index.php/Kinesik/article/view/9384/ pdf_1, diakses 28 November 2018 pukul 17:13 WIB. 
Utami, L. S. (2015). Teori-Teori Adaptasi Antarbudaya. Jurnal Komunikasi, Vol 7 No 2.https://journal.untar.ac.id/index.php/komunikasi/article/view/17/38, diakses 28 November 2018 pukul 17:40 WIB.

\section{Hasil Wawancara}

Afifah, S, 13 Februari 2019 Universitas Muhammadiyah Magelang.

Ariyati, R, S, 15 Februari 2019 Universitas Muhammadiyah Magelang.

Hendriadi, J, 10 November 2018 Universitas Muhammadiyah Magelang.

Kaltsum, U, 20 Februari 2019 Universitas Muhammadiyah Magelang.

Ningrum, M, 19 Februari 2019 Universitas Muhammadiyah Magelang.

Rabudi, 06 Maret 2019 Universitas Muhammadiyah Magelang.

Safitri, Y, 13 November 2018 Universitas Muhammadiyah Magelang.

Tildjuir, N, M, 15 Februari 2019 Universitas Muhammadiyah Magelang. 